\title{
Analysis of the Quality of Diet and Academic Performance in Rural Primary School Students
}

\author{
Pedro José Carrillo-López ${ }^{*}$, Andrés Rosa Guillamón², Eliseo García Cantó², José Enrique \\ Moral García ${ }^{3}$, and Juan José Pérez Soto²
}

${ }^{1}$ Ministry of Education, Canary Islands Government, Spain

${ }^{2}$ Faculty of Educational Sciences, University of Murcia, Murcia, Spain

${ }^{3}$ Pontifical University of Salamanca, Salamanca, Spain

\begin{abstract}
The aim was to analyze the relationship between the quality of diet and academic performance in rural primary school students, a cross-sectional study made up of 181 rural schoolchildren ( $8.75 \pm 1.79$ years) from the island of Fuerteventura. Academic performance was calculated through the average grade in the subjects described in Royal Decree 126/2014, February 28th. The quality of the Mediterranean diet was assessed through the KIDMED questionnaire. The one-way analysis of variance (ANOVA) test did not reflect statistically significant differences in academic performance as a function of the quality of the Mediterranean diet, neither in men nor in women $(p>$.005). The multinomial logistic regression test after adjusting for sex and age, reflected that schoolchildren with a higher quality of diet were more likely to have passed the areas of Social Sciences and Natural Sciences when compared to their failed peers $(p<.05)$. Thus, a higher quality of the diet in rural primary schoolchildren seems to be associated with passing the areas of Social Sciences and Natural Sciences. Health promotion professionals in the school environment must consider the positive role that diet can play in academic performance and start programs to promote healthy eating among schoolchildren.
\end{abstract}

Keywords: academic performance; cognitive health; diet; schoolchildren

Citation: Carrillo-López, P. J., Guillamón, A. R., Cantó, E. G., García, J. E. M., \& Soto, J. J. P. (2021). Analysis of the quality of diet and academic performance in rural primary school students. NeuroRegulation, 8(1), 14-21. https://doi.org/10.15540/nr.8.1.14

*Address correspondence to: Pedro José Carrillo-López, Doctor of Education, Physical Education Teacher. Ministry of Education, Canary Islands Government, Spain. Paseo Pérez Valero, 4, 38650 Los Cristianos, Santa Cruz de Tenerife. Email: pj.carrillolopez@um.es

Copyright: ( 2021. Carrillo-López et al. This is an Open Access article distributed under the terms of the Creative Commons Attribution License (CC-BY).
Edited by:

Rex L. Cannon, PhD, SPESA Research Institute, Knoxville, Tennessee, USA

\section{Reviewed by:}

Rex L. Cannon, PhD, SPESA Research Institute, Knoxville, Tennessee, USA

Randall Lyle, PhD, Mount Mercy University, Cedar Rapids, Iowa, USA

\section{Introduction}

From the current Organic Law for the Improvement of Educational Quality (LOMCE) it is extracted that one of the main objectives of the educational system in Spain is the improvement of educational quality in order to increase employability, improve results in international evaluations, unify results between communities, promote multilingualism, enhance orientation, and reduce school failure. This factor is perhaps the most significant symptom of the lack of success of the educational system (Sanz Ponce, Serrano Sarmiento, \& González Bertolín, 2020).

The fact is that, in Spain, there was $24.4 \%$ administrative failure and $19 \%$ State Agency for Tax
Administration (AET) in 2016 (according to the Ministry of Education and Eurostat, respectively), and that almost one in five students was below level two in PISA (in 2015). There are important individual and social consequences from compromising a generation of human capital and significantly reducing the opportunities of young people in relation to their future in the workplace (Yserte, Gallo-Rivera, \& Martínez-Gautier, 2020).

In this scenario, it is especially important to focus on the processes of accumulation of knowledge and skills that occur in the successive educational stages. Also, is important to analyze what factors can explain situations of school dropout or low academic performance (AP). Since the 
schoolchildren will have to function as their own advocates in a world of work where low AP will translate into the development of nonroutine jobs or tasks, with low added value and, therefore, framed in a more unstable, less protected and with lower wages (Garrido-Yserte, Gallo-Rivera, \& MartínezGautier, 2019).

In this sense, school or academic failure may be subject to different organic and environmental conditions that determine the skills and experiences of each student (Lamas, 2015). One of these factors may be the lifestyle and health behaviors adopted in childhood, since the available scientific evidence suggests that a healthy lifestyle could positively influence brain structure and function during childhood (Portolés Ariño \& González Fernández, 2015; Rosa Guillamón, García Canto, \& Carrillo López, 2019).

A healthy lifestyle that is suffering progressive abandonment in these age groups is the Mediterranean diet (Castells, 2008; García Cantó, Carrillo López, \& Rosa Guillamón, 2019), which has been recognized as intangible heritage characterized by having a wide variety of foods rich in carbohydrates, proteins, and healthy fats such as whole grains, olive oil, legumes, nuts, fruits, and vegetables (Estruch \& Ros, 2020). Some studies have described that an optimal, quality
Mediterranean diet acts as a powerful indicator of cardiovascular health (Ramón-Arbués et al., 2020). Likewise, it encourages correct psychomotor and cognitive development (Bleiweiss-Sande et al., 2019; Schwingshackl, Morze, \& Hoffmann, 2020).

Importantly, nutrients are critical for the developing brain; recent research on brain neurogenesis and plasticity confirms that good nutrition is important for optimal brain function throughout the lifecycle (Nyaradi, Li, Hickling, Foster, \& Oddy, 2013). Figure 1 gives a diagrammatic overview of the model that informs this (Parletta, Milte, \& Meyer, 2013).

In this regard, recent research in primary school students has analyzed the relationship between the quality of the diet and AP (Alfonso Rosa, Álvarez Barbosa, \& del Pozo Cruz, 2018; Esteban-Cornejo et al., 2016; Faught et al., 2017; Iglesias, Planells, \& Molina López, 2019; Mclsaac, Kirk, \& Kuhle, 2015; Nyaradi et al., 2016; Pearce et al., 2018; Vassiloudis, Yiannakouris, Panagiotakos, Apostolopoulos, \& Costarelli, 2014). A systematic review reflects that there are moderate associations between the dietary intake characterized by the consumption of foods rich in energy and poor in nutrients and the general quality of the diet with respect to the results of the AP (Burrows, Goldman, Pursey, \& Lim, 2017).

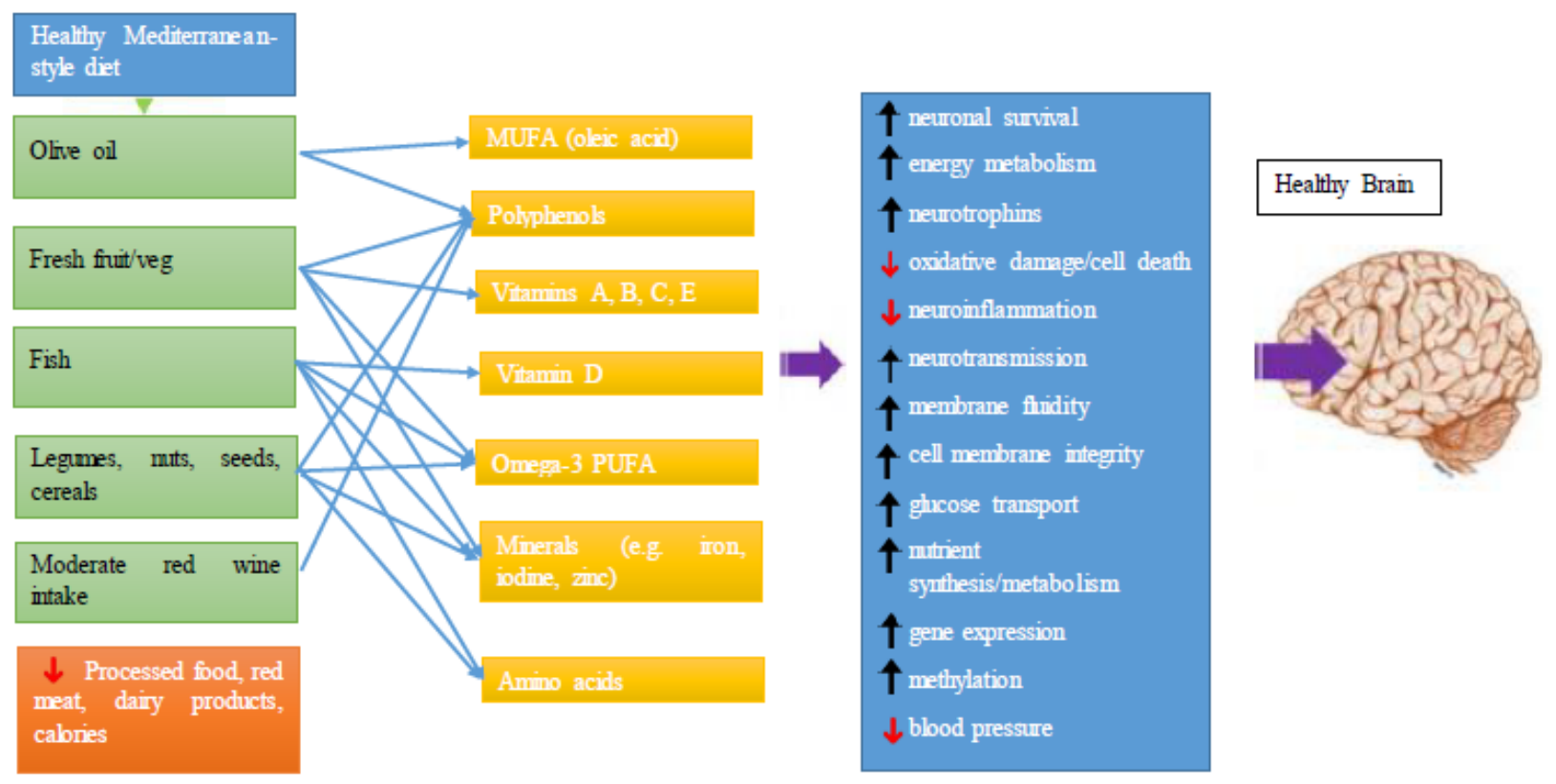

Figure 1. Overview of links between Mediterranean-style diet and healthy brain function via plant compounds/nutrients. Source: Own elaboration adapted from Parletta, Milte, and Meyer (2013). 
However, there is limited evidence on the relationship between diet quality and AP in rural residence settings, in primary school children, and in AP measured over a long period of time (BleiweissSande et al., 2019), so additional research is needed (Attuquayefio, Stevenson, Oaten, \& Francis, 2017; Dumuid et al., 2017; Haapala et al., 2017). Based on these precedents, the aim of this research was to analyze the relationship between the quality of the diet and the academic performance in rural primary school children of Fuerteventura.

\section{Methods}

\section{Study Designs}

A descriptive cross-sectional was designed ex post facto with a sample of schoolchildren belonging to a public Compulsory Education center located in a rural area (< 5000 inhabitants; LAW 45/2007, December 13th, for the development of sustainable rural environment) of the Island of Fuerteventura (Spain). The sample was made up of 181 students (99 men [54.7\%] and 82 women [45.3\%], with an age range between 8 and 13 years old (mean $M \pm$ standard deviation $S D$ : $8.75 \pm 1.79$ years) selected in a nonprobabilistic, intentional way.

\section{Procedure}

Parents of participating students were informed about the aim of the study, risks and benefits, confidentiality of data, and privacy of information. Parents were asked if they were willing to participate in the study and were told that they had the right to refuse to participate or that they could interrupt the question at any time if they felt uncomfortable answering the question. The signed and written informed consent to participate in this study was obtained from parents and guardians since our study population was children under 18 years old.

Academic performance was assessed by means of the average grade obtained by the students in the first and second evaluation of the academic year $2019 / 2020$, carried out in the different compulsory subjects to be taken according to what is indicated in the Primary Education curriculum (Royal Decree 126/2014, February 28th): Natural Sciences, Social Sciences, Spanish Language and Literature, Mathematics, and English. The values of all the variables ranged between a score between 1 and 10 points. Depending on the grade they obtained, the students were categorized into failed ( $A ; \leq 4$ points) and passed ( $B ; \geq 5$ points).

On the one hand, through the KIDMED questionnaire the quality of the Mediterranean diet was assessed (Serra-Majem et al., 2004). This questionnaire, composed of 16 dichotomous questions, has been widely used in the infant and young population (García Cantó et al., 2019; Rosa Guillamón et al., 2019). Its score can have a range between 0 and 12 points. Questions with a negative connotation acquire a negative value of one point, which are then summed with the positive scores; the sample is classified into three levels according to its diet quality: (I) $\geq 8$, optimal; (II) $4-7$, to improve; (III) $\leq 3$, low quality.

The KIDMED questionnaire was completed by the participants in a large room with the presence of the research doctor from the Department of Plastic, Musical and Dynamic Expression of the University of Murcia, Spain. This expert on the subject explained and resolved all doubts before distributing the instrument, which also contained the sociodemographic variables: sex, age, and school year.

The protection of personal data was taken into account in order to safeguard the rights, safety, and well-being of the respondents. All of the students participated voluntarily, respecting the Helsinki research ethics agreement (2013), the current Spanish legal regulation 118 that regulates clinical research in humans (Royal Decree 561/1993 on clinical trials) and the ethical code of good practices in internships at the University of Murcia.

\section{Data Analysis}

The mean $(M)$ and standard deviation $(S D)$ are reported for all quantitative variables. The normality of the distributions was verified by the KolmogorovSmirnov test with Lilliefors correction, as well as the homogeneity of the variances by the Levene test. Subsequently, when observing a normal distribution in part of the distributions of the registered values, a parametric analysis has been chosen. A simple analysis of variance (one-way ANOVA) was used to analyze the AP values as a function of the quality of the Mediterranean diet (Low, Medium, High). The effect size was calculated using Cohen's $d(.20$, small; .50, medium; and .80, large effect). In addition, an analysis of bivariate and partial correlations (Pearson's test) was carried out between the quality of the diet and the different academic subjects grouped and without grouping. Finally, it was decided to perform a multinomial logistic regression to observe the probability of obtaining different results depending on whether the students failed or passed the subject. This analysis was set to an adjusted odds ratio (OR), without adjusting for the variables of age and sex. The data 
were analyzed with the statistical program SPSS (v.25.0). Statistical significance was set at $p<.05$.

\section{Results}

Data on age and mean score obtained in academic subjects according to adherence to MD are shown in Table 1, for both men and women. The only statistically significant differences were found for age, being in favor of women ( $p=.032 ; d=.22$ ).

Table 2 shows the different bivariate and partial correlations observed according to the KIDMED index score and the academic subjects, adjusting and without adjusting for age and sex. No statistically significant correlation was found between the KIDMED index score and adjusted academic subjects or without adjusting for age and sex.

Finally, Table 3 presents the results of the multivariate analysis to provide a predictive analysis of the quality of the diet on academic performance. Adjusting and without adjusting for age and sex, having a higher quality of diet is associated with a greater probability of passing the areas of Natural Sciences $(p<.05)$ and Social Sciences $(p<.05)$.

\section{Table 1}

Sample descriptive data according to the quality of the Mediterranean diet.

\begin{tabular}{|c|c|c|c|c|c|c|c|c|c|c|}
\hline Variables & $\begin{array}{c}\text { Low QD } \\
\begin{array}{c}n=13 \\
(\%)\end{array}\end{array}$ & $\begin{array}{c}\text { Medium QD } \\
\begin{array}{c}n=59 \\
(\%)\end{array}\end{array}$ & $\begin{array}{l}\text { High QD } \\
\begin{array}{c}n=27 \\
(\%)\end{array}\end{array}$ & $p$ & $d$ & $\begin{array}{c}\text { Low QD } \\
n=12 \\
(\%)\end{array}$ & $\begin{array}{c}\text { Medium QD } \\
n=49 \\
(\%)\end{array}$ & $\begin{array}{c}\text { High QD } \\
\begin{array}{c}n=21 \\
(\%)\end{array}\end{array}$ & $p$ & $d$ \\
\hline Natural Sciences & $6.76 \pm 1.5$ & $6.28 \pm 2.1$ & $6.18 \pm 2.2$ & .702 & .02 & $7.16 \pm 1.6$ & $7.10 \pm 1.9$ & $6.19 \pm 1.9$ & .164 & .16 \\
\hline Social Sciences & $6.46 \pm 1.7$ & $6.32 \pm 2.2$ & $5.96 \pm 2.5$ & .737 & .01 & $6.75 \pm 2.0$ & $7.22 \pm 2.0$ & $7.04 \pm 1.8$ & .747 & .02 \\
\hline $\begin{array}{l}\text { Spanish Language } \\
\text { and Literature }\end{array}$ & $6.38 \pm 1.7$ & $6.28 \pm 1.9$ & $5.91 \pm 2.2$ & .701 & .03 & $7.33 \pm 1.4$ & $6.67 \pm 2.2$ & $6.52 \pm 1.9$ & .542 & .08 \\
\hline English & $6.76 \pm 1.7$ & $6.52 \pm 2.2$ & $6.55 \pm 2.1$ & .936 & .01 & $7.41 \pm 1.7$ & $7.04 \pm 1.8$ & $6.81 \pm 2.0$ & .691 & .09 \\
\hline Artistic education & $5.92 \pm 1.0$ & $6.00 \pm 1.1$ & $6.29 \pm 1.0$ & .444 & .10 & $6.66 \pm 0.9$ & $6.59 \pm 0.8$ & $6.47 \pm 0.8$ & .810 & .02 \\
\hline Physical education & $7.61 \pm 1.1$ & $7.96 \pm 0.9$ & $8.03 \pm 0.8$ & .423 & .10 & $8.25 \pm 0.8$ & $8.24 \pm 0.8$ & $8.19 \pm 0.8$ & .967 & .01 \\
\hline Core subjects & $6.64 \pm 1.5$ & $6.39 \pm 1.9$ & $6.21 \pm 2.0$ & .795 & .05 & $7.25 \pm 1.5$ & $7.00 \pm 1.8$ & $6.62 \pm 1.7$ & .579 & .09 \\
\hline Specific Subjects & $6.87 \pm 1.1$ & $6.92 \pm 1.1$ & $7.07 \pm 1.0$ & .802 & .06 & $7.47 \pm 1.0$ & $7.42 \pm 0.9$ & $7.33 \pm 0.9$ & .909 & .01 \\
\hline
\end{tabular}

Note. One-way ANOVA statistical test. 


\begin{tabular}{|c|c|c|}
\hline \multicolumn{3}{|c|}{$\begin{array}{l}\text { Table } 2 \\
\text { Bivariate and partial correlations between the mean } \\
\text { score of the KIDMED index and the different } \\
\text { variables of the study. }\end{array}$} \\
\hline Variables & $\begin{array}{l}\text { Not Adjusted } \\
R \text { ( } p \text {-value) }\end{array}$ & $\begin{array}{l}\text { Adjusted * } \\
R \text { (p-value) }\end{array}$ \\
\hline Natural Sciences & $.080(.283)$ & $.075(.317)$ \\
\hline Social Sciences & .025 (.738) & $.039(.603)$ \\
\hline $\begin{array}{l}\text { Spanish Language } \\
\text { and Literature }\end{array}$ & $-.072(.820)$ & $-.068(.367)$ \\
\hline Mathematics & $-.065(.384)$ & $-.060(.428)$ \\
\hline English & $-.012(.868)$ & $-.060(.428)$ \\
\hline Artistic education & $.111(.138)$ & $.119(.113)$ \\
\hline Physical education & $.067(.371)$ & $.078(.298)$ \\
\hline Core subjects & $-.045(.550)$ & $-.038(.617)$ \\
\hline Specific Subjects & $.059(.431)$ & $.076(.314)$ \\
\hline
\end{tabular}

Note. Adjusted for sex and age *

\section{Table 3}

Academic performance according to the quality of the Mediterranean diet.

\begin{tabular}{|c|c|c|}
\hline Variables & $\begin{array}{c}\text { Model I } \\
\text { OR (IC 95\%) } \\
\text { p-value }\end{array}$ & $\begin{array}{c}\text { Model II } \\
\text { OR (IC 95\%) } \\
p \text {-value }\end{array}$ \\
\hline \multirow[t]{2}{*}{ Natural Sciences } & $0.556(0.37-1.07)$ & $0.535(0.29-0.97)$ \\
\hline & .053 & .041 \\
\hline \multirow[t]{2}{*}{ Social Sciences } & $1.867(1.04-3.20)$ & $2.131(1.17-3.87)$ \\
\hline & .030 & .013 \\
\hline \multirow{2}{*}{$\begin{array}{l}\text { Spanish Language } \\
\text { and Literature }\end{array}$} & $0.836(0.47-1.46)$ & $0.758(0.42-1.35)$ \\
\hline & .529 & .347 \\
\hline \multirow[t]{2}{*}{ Mathematics } & $0.779(0.46-1.30)$ & $0.776(0.46-1.29)$ \\
\hline & .342 & .334 \\
\hline \multirow[t]{2}{*}{ English } & $0.940(0.61-1.40)$ & $0.934(0.60-1.43)$ \\
\hline & .773 & .754 \\
\hline \multirow[t]{2}{*}{ Artistic education } & $1.331(0.57-3.09)$ & $1.211(0.49-2.97)$ \\
\hline & .507 & .676 \\
\hline \multirow[t]{2}{*}{ Physical education } & $1.694(0.72-3.96)$ & $1.686(0.71-3.96)$ \\
\hline & .225 & .231 \\
\hline \multirow[t]{2}{*}{ Core subjects } & $0.621(0.22-2.60)$ & $0.635(0.28-3.10)$ \\
\hline & .456 & .779 \\
\hline \multirow[t]{2}{*}{ Specific Subjects } & $0.966(0.23--3.97)$ & $1.235(0.28-5.37)$ \\
\hline & .966 & .799 \\
\hline
\end{tabular}

Note. Multinomial logistic regression considering the approved category. Model I: not adjusted for sex and age. Model II: adjusted to the sex and age of the participants.

\section{Discussion}

The aim of this study was to analyze the relationship between the quality of the Mediterranean diet and academic performance in rural schoolchildren on the island of Fuerteventura considering and without considering sex and age. The main findings of the study show that, after adjusting for sex and age, schoolchildren with a higher quality of diet were more likely to pass the areas of Social Sciences and Natural Sciences when compared to their failing peers.

These results coincide with those found in other investigations both in primary school students (Dumuid et al., 2017; Mclsaac et al., 2015; Vassiloudis et al., 2014) and secondary education (Ibarra Mora, Hernández Mosqueira, \& Ventura-VallLlovera, 2019), as well as in the university stage (Gimeno Tena \& Esteve Clavero, 2020), where they detected a higher AP in the group of schoolchildren with the highest quality of diet.

It should be noted that in another investigation only an association was found between adherence to the Mediterranean diet and the grades obtained in Art Education, Mathematics, and Social Sciences in schoolchildren in Spain (Alfonso Rosa et al., 2018); while in Australian schoolchildren, a better quality diet was only associated with significantly higher scores in math, reading, writing, and spelling (Nyaradi et al., 2016). Considering compliance with international nutritional recommendations, (Faught et al., 2019) reflected that children who met current recommendations for protein-rich foods obtained an average of $5.67 \%$ and $3.45 \%$, respectively, better in exams. Although the results indicated that adherence to dietary recommendations was beneficial for girls' AP, no results were statistically significant.

In a systematic review, only moderate associations were found between lower intakes of energy-rich and nutrient-poor foods and overall diet quality with respect to AP results (Burrows et al., 2017), and unlike Pearce et al. (2018) where they only found that AP was negatively associated with a nutrientpoor, energy-dense diet, but not with a nutritious diet. In this sense, Esteban-Cornejoet al. (2016) reflected that the benefits of adherence to the Mediterranean diet over AP seem to be stronger as young people adhere to the optimal levels of the Mediterranean diet. For example, Iglesias et al. (2019) only found that a low consumption of fruits, vegetables, and dairy products was related to a worse AR. 
In this regard, a systematic review of micronutrient supplementation evaluated through randomized controlled trials suggested that only certain micronutrients appear to be associated with a marginal increase in fluent intelligence (based on reasoning skills, comparable to mathematics) but not with crystallized intelligence (verbal comprehension and vocabulary, comparable to ELA; Eilander et al., 2010). For its part, a dietary intervention rich in saturated fat for 4 days caused reductions in learning and memory dependent on the hippocampus and interoceptive sensitivity
(Attuquayefio et al., 2017). In addition, the Mediterranean diet has been shown to be antioxidant, given the high consumption of fruits and vegetables. Highly toxic molecules can lead to alterations in cell lipid membranes and cellular functions, and oxidized proteins, DNA, RNA, and cell death, contributing to a variety of chronic degenerative diseases, including cardiovascular disease, cancer, and premature aging (Gandhi \& Abramov, 2012). Figure 2 gives a diagrammatic overview of the model that informs this.

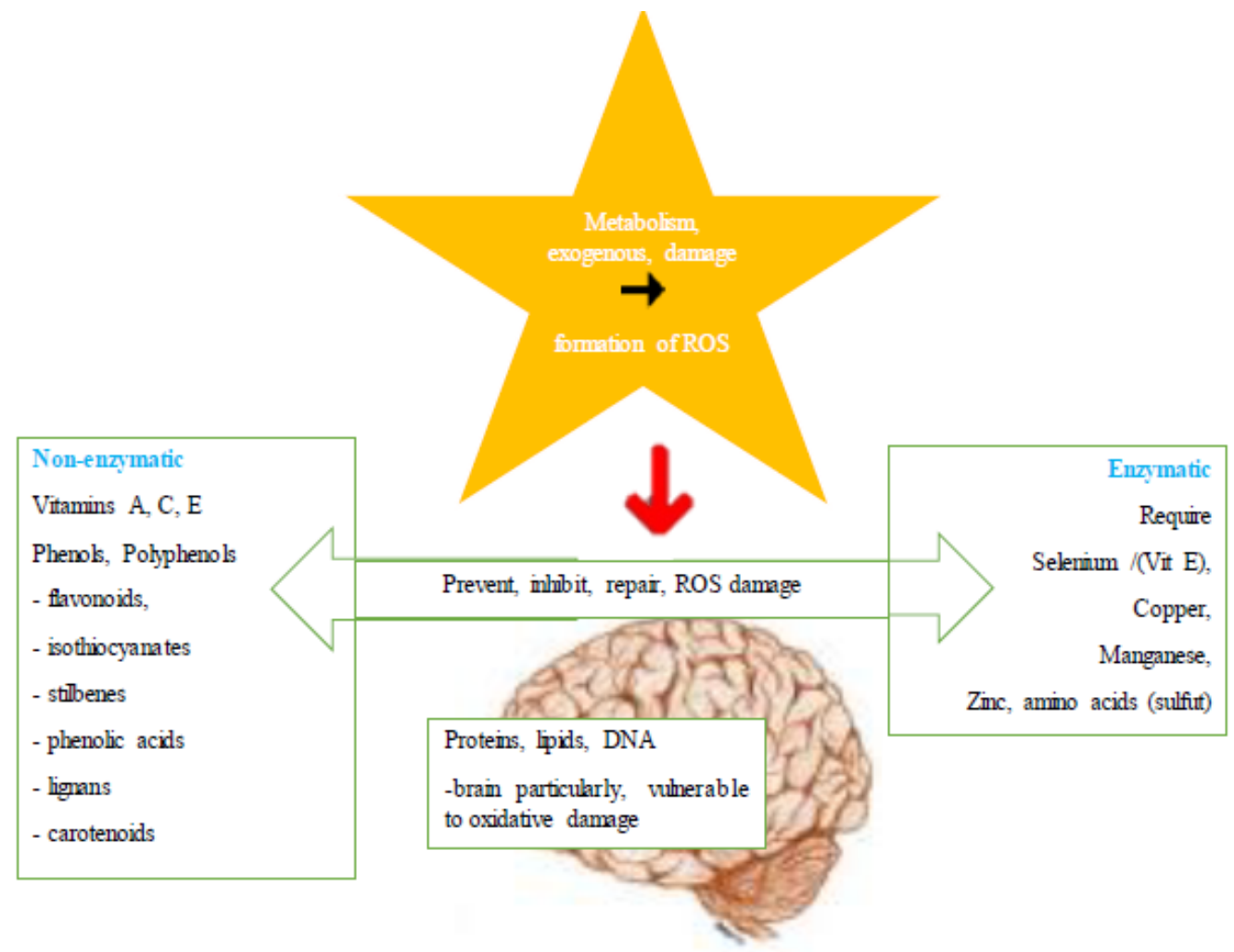

Figure 2. Antioxidant and brain overview. ROS = reactive oxygen species. Source: Own elaboration adapted from Parletta, Milte, and Meyer (2013).

Therefore, the results obtained in this study may be due to the fact that within the brain, the hippocampus is particularly sensitive to the modulation of lifestyle factors such as the Mediterranean diet. It is known that this brain structure is essential for learning and memory and for progress in the classroom, which is why it can condition AP (Hassevoort, Khan, Hillman, \& Cohen, 2016).

In this sense, in schools where programs to improve the quality of the diet have been included, an improvement in AP has been obtained (Nathan et al., 2016). However, and inconsistent with this substantial evidence base, there has been a growing trend to decrease the encouragement of activities in school that promote health and to view these activities as nonessential rather than activities fundamental to the academic activity of schools (Schwingshackl et al., 2020). Therefore, the results of this study add to the growing understanding of the associations between health behaviors and AP and provide further justification for the importance of health promotion interventions to support learning 
goals and health in schools. In turn, it should be noted that our current study has several strengths, including the use of a population-based sample of rural schoolchildren aged 8 to 13 years and the use of academic performance scores obtained during an entire academic quarter.

However, our findings should be interpreted with caution due to the fact that this study was not interventionist but was based on data reported by schoolchildren, with an unknown quality and quantity of the food consumed daily by them. In turn, it is difficult to infer a cause-and-effect relationship between diet and AR, since there are confounding factors that probably influence AR that were not considered in this study, which would explain why our study did not find any partial or bivariate correlation between AP and diet quality. In this sense, Sørensen et al. (2016) reflected that the effects of healthy school meals on reading, impulsivity, and inattention were modified according to gender, education home, and reference reading skills. Therefore, these differential effects could be related to environmental aspects and deserve to be further investigated in future school meal trials. Likewise, the disparity of results in the set of investigations on these relationships may come as a consequence of the way of measuring or quantifying the AR.

\section{Conclusion}

The present study contributes to the scientific literature that investigates the relationship between healthy lifestyle habits, such as the quality of diet, and academic performance. Based on these results, it is concluded that a lower quality of the diet is associated with a lower academic performance in the areas of Social Sciences and Natural Sciences in rural primary school students. Future studies should shed more light on this association. Mainly, long-term and intervention studies are needed. Meanwhile, health promotion professionals in the school environment must consider the positive role that diet can play in academic performance and initiate programs to promote healthy eating among schoolchildren.

\section{Author Disclosure}

Authors have no grants, financial interests, or conflicts to disclose.

\section{References}

Alfonso Rosa, R. M., Álvarez Barbosa, F., \& del Pozo Cruz, J. (2018). Adherencia a la dieta mediterránea, el rendimiento académico y el nivel de actividad física en edad escolar.
Sportis, Scientific Journal of School Sport, Physical Education and Psychomotricity, 4(2), 255-268. https://doi.org/10.17979 /sportis.2018.4.2.3108

Attuquayefio, T., Stevenson, R. J., Oaten, M. J., \& Francis, H. M. (2017). A four-day Western-style dietary intervention causes reductions in hippocampal-dependent learning and memory and interoceptive sensitivity. PLOS ONE, 12(2), e0172645. https://doi.org/10.1371/journal.pone.0172645

Bleiweiss-Sande, R., Chui, K., Wright, C., Amin, S., AnzmanFrasca, S., \& Sacheck, J. M. (2019). Associations between food group intake, cognition, and academic achievement in elementary schoolchildren. Nutrients, 11(11), 2722. https://doi.org/10.3390/nu11112722

Burrows, T., Goldman, S., Pursey, K., \& Lim, R. (2017). Is there an association between dietary intake and academic achievement: A systematic review. Journal of Human Nutrition and Dietetics, 30(2), 117-140. https://doi.org /10.1111/jhn. 12407

Castells, M. (2008). El reconocimiento internacional de la Dieta Mediterránea como Patrimonio inmaterial: Oportunidades para el turismo gastronómico balear. Boletín Gestión Cultural, 17, 2-16.

Dumuid, D., Olds, T., Martín-Fernández, J.-A., Lewis, L. K., Cassidy, L., \& Maher, C. (2017). Academic performance and lifestyle behaviors in Australian school children: A cluster analysis. Health Education \& Behavior, 44(6), 918-927. https://doi.org/10.1177/1090198117699508

Eilander, A., Gera, T., Sachdev, H. S., Transler, C., van der Knaap, H. C. M., Kok, F. J., \& Osendarp, S. J. M. (2010). Multiple micronutrient supplementation for improving cognitive performance in children: Systematic review of randomized controlled trials. The American Journal of Clinical Nutrition, 91(1), 115-130. https://doi.org/10.3945/ajcn.2009.28376

Esteban-Cornejo, I., Izquierdo-Gomez, R., Gómez-Martínez, S., Padilla-Moledo, C., Castro-Piñero, J., Marcos, A., \& Veiga, O. L. (2016). Adherence to the Mediterranean diet and academic performance in youth: The UP\&DOWN study. European Journal of Nutrition, 55(3), 1133-1140. https://doi.org/10.1007 /s00394-015-0927-9

Estruch, R., \& Ros, E. (2020). The role of the Mediterranean diet on weight loss and obesity-related diseases. Reviews in Endocrine and Metabolic Disorders, 21, 315-327. https://doi.org/10.1007/s11154-020-09579-0

Faught, E. L., Ekwaru, J. P., Gleddie, D., Storey, K. E., Asbridge, M., \& Veugelers, P. J. (2017). The combined impact of diet, physical activity, sleep and screen time on academic achievement: A prospective study of elementary school students in Nova Scotia, Canada. International Journal of Behavioral Nutrition and Physical Activity, 14(1), 29. https://doi.org/10.1186/s12966-017-0476-0

Faught, E. L., Qian, W., Carson, V. L., Storey, K. E., Faulkner, G., Veugelers, P. J., \& Leatherdale, S. T. (2019). The longitudinal impact of diet, physical activity, sleep, and screen time on Canadian adolescents' academic achievement: An analysis from the COMPASS study. Preventive Medicine, 125, 24-31. https://doi.org/10.1016/j.ypmed.2019.05.007

Gandhi, S., \& Abramov, A. Y. (2012). Mechanism of oxidative stress in neurodegeneration. Oxidative Medicine and Cellular Longevity, 2012, 428010. https://doi.org/10.1155/2012 1428010

García Cantó, E., Carrillo López, P. J., \& Rosa Guillamón, A. (2019). Análisis de la dieta mediterránea en escolares de Primaria, Secundaria y Bachillerato (Analysis of the Mediterranean diet in Primary, Secondary and high shool students). Revista Chilena de Nutrición, 46(4), 469-476. https://doi.org/10.4067/S0717-75182019000400469

Garrido-Yserte, R., Gallo-Rivera, M. T., \& Martínez-Gautier, D. (2019). Más allá de las aulas: Los determinantes del bajo rendimiento educativo en España y el fracaso de las políticas públicas. International Review of Economic Policy. Revista 
Internacional de Política Económica, 1(1), 86-106. https://doi.org/10.7203/IREP.1.1.16459

Gimeno Tena, A., \& Esteve Clavero, A. (2020). Factores nutricionales y rendimiento académico. Estudio piloto. Ágora de Salut, 7, 127-134. https://doi.org/10.6035 /AgoraSalut.2020.7.13

Haapala, E. A., Eloranta, A.-M., Venäläinen, T., Jalkanen, H., Poikkeus, A.-M., Ahonen, T., \& Lakka, T. A. (2017). Diet quality and academic achievement: A prospective study among primary school children. European Journal of Nutrition, 56(7), 2299-2308. https://doi.org/10.1007/s00394016-1270-5

Hassevoort, K. M., Khan, N. A., Hillman, C. H., \& Cohen, N. J. (2016). Childhood markers of health behavior relate to hippocampal health, memory, and academic performance. Mind, Brain, and Education, 10(3), 162-170. https://doi.org $/ 10.1111 / \mathrm{mbe} .12108$

Ibarra Mora, J., Hernández Mosqueira, C. M., \& Ventura-VallLlovera, C. (2019). Hábitos alimentarios y rendimiento académico en escolares adolescentes de Chile. Revista Española de Nutrición Humana y Dietética, 23(4), 292-301. https://doi.org/10.14306/renhyd.23.4.804

Iglesias, Á., Planells, E., \& Molina López, J. (2019). Prevalencia de sobrepeso y obesidad, hábitos alimentarios y actividad física y su relación sobre el rendimiento académico (Prevalence of overweight and obesity, exercise, and dietary habits, and their relation with academic achievement). Retos, 36, 167-173. https://doi.org/10.47197/retos.v36i36.66873

Lamas, H. A. (2015). Sobre el rendimiento escolar. Propósitos y Representaciones, 3(1), 313-386. https://doi.org/10.20511 /pyr2015.v3n1.74

Mclsaac, J.-L. D., Kirk, S. F. L., \& Kuhle, S. (2015). The association between health behaviours and academic performance in Canadian elementary school students: A cross-sectional study. International Journal of Environmental Research and Public Health, 12(11), 14857-14871. https://doi.org/10.3390/ijerph121114857

Nathan, N., Yoong, S. L., Sutherland, R., Reilly, K., Delaney, T., Janssen, L., ... Wolfenden, L. (2016). Effectiveness of a multicomponent intervention to enhance implementation of a healthy canteen policy in Australian primary schools: A randomised controlled trial. International Journal of Behavioral Nutrition and Physical Activity, 13(1), 106. https://doi.org/10.1186/s12966-016-0431-5

Nyaradi, A., Li, J., Foster, J. K., Hickling, S., Jacques, A., O'Sullivan, T. A., \& Oddy, W. H. (2016). Good-quality diet in the early years may have a positive effect on academic achievement. Acta Paediatrica, 105(5), e209-e218. https://doi.org /10.1111/apa.13324

Nyaradi, A., Li, J., Hickling, S., Foster, J., \& Oddy, W. H. (2013). The role of nutrition in children's neurocognitive development, from pregnancy through childhood. Frontiers in Human Neuroscience, $\quad 7, \quad 97 . \quad$ https://doi.org/10.3389 /fnhum.2013.00097

Parletta, N., Milte, C. M., \& Meyer, B. J. (2013). Nutritional modulation of cognitive function and mental health. The Journal of Nutritional Biochemistry, 24(5), 725-743. https://doi.org/10.1016/j.jnutbio.2013.01.002

Pearce, K., Golley, R., Lewis, L., Cassidy, L., Olds, T., \& Maher, C. (2018). The apples of academic performance: Associations between dietary patterns and academic performance in
Australian children. Journal of School Health, 88(6), 444-452. https://doi.org/10.1111/josh.12631

Portolés Ariño, A., \& González Fernández, J. (2015). Rendimiento académico y correspondencias con indicadores de salud física y psicológica. Sportis. Scientific Journal of School Sport, Physical Education and Psychmotricity, 1(2), 164-181. https://doi.org/10.17979/sportis.2015.1.2.1409

Ramón-Arbués, E., Martínez-Abadía, B., Granada-López, J. M. Echániz-Serrano, E., Huércanos-Esparza, I., \& AntónSolanas, I. (2020). Asociación entre la adherencia a la dieta mediterránea y la prevalencia de factores de riesgo cardiovascular (Association between adherence to the Mediterranean diat and the prevalence of cardiovascular risk factors). Revista Latino-Americana de Enfermagem, 28, e3295. https://doi.org/10.1590/1518-8345.3904.3295

Rosa Guillamón, A., García Canto, E., \& Carrillo López, P. J. (2019). Capacidad aeróbica y rendimiento académico en escolares de educación primaria (Aerobic capacity and academic performance in primary schoolchildren). Retos, 35, 351-354. https://doi.org/10.47197/retos.v0i35.66769

Sanz Ponce, R., Serrano Sarmiento, Á., \& González Bertolín, A. (2020). PISA: El precio pedagógico de una evaluación internacional. Revista Electrónica de Investigación Educativa, 22, e22, 1-13. https://doi.org/10.24320 /redie.2020.22.e22.2673

Schwingshackl, L., Morze, J., \& Hoffmann, G. (2020). Mediterranean diet and health status: Active ingredients and pharmacological mechanisms. British Journal of Pharmacology, 177(6), 1241-1257. https://doi.org/10.1111 /bph.14778

Serra-Majem, L., Ribas, L., Ngo, J., Ortega, R. M., García, A., Pérez-Rodrigo, C., \& Aranceta, J. (2004). Food, youth and the Mediterranean diet in Spain. Development of KIDMED, Mediterranean Diet Quality Index in children and adolescents. Public Health Nutrition, 7(7), 931-935. https://doi.org/10.1079 /PHN2004556

Sørensen, L. B., Damsgaard, C. T., Petersen, R. A., Dalskov, S.M., Hjorth, M. F., Dyssegaard, C. B., ... Michaelsen, K. F. (2016). Differences in the effects of school meals on children's cognitive performance according to gender, household education and baseline reading skills. European Journal of Clinical Nutrition, 70(10), 1155-1161. https://doi.org/10.1038/ejcn.2016.99

Vassiloudis, I., Yiannakouris, N., Panagiotakos, D. B., Apostolopoulos, K., \& Costarelli, V. (2014). Academic performance in relation to adherence to the Mediterranean diet and energy balance behaviors in Greek primary schoolchildren. Journal of Nutrition Education and Behavior, 46(3), 164-170. https://doi.org/10.1016/j.jneb.2013.11.001

Yserte, R. G., Gallo-Rivera, M. T., \& Martínez-Gautier, D. (2020). ¿Cuáles son y cómo operan los determinantes del fracaso escolar? Replanteando las políticas públicas para el caso de España y sus regiones. RICEG, Revista Internacional de Ciencias del Estado y de Gobierno, 1(4), 509-540.

Received: February 11, 2021

Accepted: February 22, 2021

Published: March 29, 2021 